\title{
Commentary Job design meets organizational sociology
}

\author{
GERALD F. DAVIS* \\ Ross School of Business, The University of Michigan, Ann Arbor, Michigan, U.S.A.
}

The world of work has seen a vast transformation in the three decades since Hackman and Oldham published their foundational research on work redesign. At the broadest level, the US has nearly completed the transition from a manufacturing to a service economy foretold by Daniel Bell (1973). By 2010, perhaps as little as 10 per cent of the American workforce will be employed in agriculture and manufacturing - growing food and making things. During the years of the Bush administration, the manufacturing sector suffered a net loss of 4.2 million jobs - about one in four. Although the steep decline in manufacturing employment is often attributed to offshoring, another fundamental source of job loss is productivity growth. The US still leads the world in manufacturing value added, with almost one-quarter of the world's total. It simply no longer takes as many people to accomplish this. Just as 1 per cent of the population is sufficient to produce all the food we need, it is possible to foresee a time when less than 5 per cent of the workforce produces all the manufactured goods we need.

Where are the jobs now? Today, nine of the 12 largest American employers are in retail or fast food. (In descending order, these are Wal-Mart, UPS, McDonald's, Target, Kroger, AT\&T, Sears Holdings, Home Depot, Verizon, Walgreen, Lowe's, and Safeway). Wal-Mart alone employs more Americans than the 15 largest manufacturers combined. Thus, the modal job in America today involves selling things, not making them.

There is also greater job insecurity at a macro level. Economist Alan Blinder (2006) estimates that in a global economy with widespread access to high-speed internet connections (that is, Thomas Friedman's "flat world"), 40 million jobs in the US are at risk of going offshore, from tutoring students and collecting debts to processing tax returns and reading X-rays. This is an unprecedented shift, increasing the level of competition among laborers around the world. Since the US has historically lacked a substantial welfare state and instead left it to employers to provide for health care and retirement security, the risks of such transitions are great. (Davis, 2009: Chapter 6 provides a grim assessment of the contemporary world of work in the US.)

For the jobs that remain, the reorganization of work through successive waves of outsourcing and vertical dis-integration has meant that many more employees are stuck in jobs without career ladders. When the mailroom was an entry-level position, young workers could aspire to move up within the company, but now the mailroom is operated by a specialized contractor, as are payroll, accounting, and maintenance. Far more jobs today are dead-ends compared to the situation in previous generations, which limits the tools available to those managing the workforce and constrains economic mobility for employees (Applebaum, Bernhardt, \& Murnane, 2003; Corak, 2004).

* Correspondence to: Gerald F. Davis, Ross School of Business, The University of Michigan, 701 Tappan St., Ann Arbor, Michigan, U.S.A. E-mail: gfdavis@umich.edu 
At a narrower level, some of the worst excesses of Taylorism have come to the service sector. Jobs in retail are distinguished by low wages (about $\$ 11$ per hour on average), low tenure (a median of 3 years), and extremely limited career prospects. Although the job design literature seems to laud "flat" organizations for providing more meaningful and autonomous work and the prospect for designing one's own job (e.g., Grant, Fried, \& Juillerat, 2009), it is not obvious how well this applies in retail. A flat hierarchy is entirely consistent with low autonomy on the job. Indeed, the spread of "workforce management" software systems in the past few years has tightened the constraints on many retail employees. A recent story in the Wall Street Journal describes how the new workforce management systems operate: AnnTaylor Stores installed a system last year. When saleswoman Nyla Houser types her code number into a cash register at the Ann Taylor store here at the Oxford Valley Mall, it displays her 'performance metrics': average sales per hour, units sold, and dollars per transaction. The system schedules the most productive sellers to work the busiest hours. . Current and former employees of the Langhorne store say that within months of the system's installation in May 2007, the culture shifted from collegial to highly competitive [as salespeople stole each others' customers to get their numbers up]... It used to be up to store managers to come up with weekly schedules for employees and to accommodate their personal preferences. The system automated that task. . .In the Princeton, NJ, store, employees were given headsets so managers could announce store-wide sales levels and remark on the performance of individual employees. .." (O'Connell, 2008). Such a workplace sounds less like a bossfree workers' paradise than a corporate panopticon-Jeremy Bentham's circular prison in which one guard in the center can observe all inmates at once and prisoners never know when they are being watched.

The logic of the sweatshop extends to unlikely places these days. One job that would have been hard to imagine in the heyday of the job design literature is the "gold farmer." Gold farmers play online multiplayer games such as World of Warcraft, gathering points ("gold") through completing various mundane tasks. These points, in turn, can be sold to "recreational" players in the US that want to skip the dull parts of the game and head straight to the action. There are an estimated 100000 gold farmers in China, many living in company dorms and playing routine games all day in electronic sweatshops for a piece rate that works out to perhaps 30 cents per hour (Dibbell, 2007). As these examples show, job design is intrinsically tied up with central concerns of sociology: globalization, technology, changes in capitalist work organization, and their effects on class mobility.

This commentary describes how sociological approaches to organizations-particularly new institutional theory (NIT)-can mutually benefit from exchange with the literature on job design. I first give a brief description of NIT and its basic approach to research, with illustrative examples in the study of human resource practices. I then briefly describe what NIT could learn from the study of job design, and what job design researchers might learn from NIT, and suggest potential new research directions. I conclude by arguing that the new world of post-industrial work would benefit from greater crossover among organizational sociologists-who typically examine broad trends-and those that study job design in practice. Work is undoubtedly being redesigned on a large scale; whether for better or worse remains to be seen.

\section{New Institutional Theory: the Reader's Digest Version}

New institutional theory (NIT) arose within sociology during the late 1970s and early 1980s in response to the advent of post-industrialism in the US. Manufacturing firms had long been the paradigmatic “organizations" in organization theory (e.g., Thompson, 1967; Scott \& Davis, 2007). They had 
tangible inputs, throughputs, and outputs, and it was possible to imagine physical measures of performance and efficiency that might be enhanced by thoughtful organization design. But researchers in the 1970s observed that many organizations were in industries such as education or social work that lacked the tangible, measurable qualities of physical production. In such contexts, organizations were often held accountable not for what they did, but how they did it-not the quantity or quality of the goods produced, but whether the staff had appropriate credentials, or whether the firm had offices of quality assurance (Meyer \& Rowan, 1977). That is, organizations were evaluated in terms of their legitimacy, defined as "a generalized perception or assumption that the actions of an entity are desirable, proper, or appropriate within some socially constructed system of norms, values, beliefs, and definitions" (Suchman, 1995: 574). For post-industrial organizations in particular, legitimacy was often more important than efficiency or effectiveness in ensuring the organization's fitness for its environment.

A basic theme of the institutional approach is that as such standards of evaluation spread, organizations and societies come to be more similar over time. Even though they may operate in very different sectors, organizations often seemed to look alike. The societal analogy is "McDonaldization"-the sense that every town has become almost indistinguishable from the next, as they are invaded by the same set of generic chain stores and restaurants that reproduce themselves like a computer virus across the landscape. Similarly, organizations all seem to adopt the same structures and practices, no matter how ill-suited to their situation. Hospitals adopt "total quality management" techniques developed in manufacturing in order to please outside evaluators. Nonprofit organizations measure their "deliverables" with "metrics" promulgated by the retired venture capitalists that control their funding. Consumer packaged goods companies create ceremonial offices of social responsibility to draw attention away from the labor practices of their suppliers.

NIT points to several mechanisms to account for this organizational conformity. First, governments often create ambiguous regulations, and organizations respond in ways just sufficient to fend off further intervention. Managers balance their need to demonstrate their compliance with outside evaluators with their desire for autonomy by ceremonially creating structures that are often decoupled from the real work of the organizations. Second, professions provide a mechanism for the spread of practices through their training, networks, and professional associations. Organizations find themselves employing lawyers, MBAs, human resource managers, and others that are trained in the same techniques and "best practices" at the same schools. Over time, these organizations come to conform to the same legitimate template of what a well-run organization is supposed to look like (DiMaggio \& Powell, 1983).

NIT suggests two broad methodological dicta. First, institutionalists take the field as the appropriate unit of analysis. A field is "a community of organizations that partakes of a common meaning system and whose participants interact more frequently and fatefully with one another than with actors outside the field" (Scott, 1995:p. 56). If "best practices" are an attribute of a field (e.g., best practices for nonprofits, or health care, or financial services), then it makes more sense to examine their spread and prevalence at the level of a relevant collective than at the level of the actor (organization). Just as one cannot observe the diffusion of an innovation at the individual level, one cannot see field-level norms without observing the entire field. Second, institutionalists look to networks that tie the constituents of a field into a coherent whole and that provide a substrate for the sharing of ideas and practices-shared directors, personnel flows, common professional associations, and so on (see Scott \& Davis, 2007 for a review).

Human resource practices have been among the best-studied phenomena by institutionalists. Many of the practices taken to be hallmarks of enlightened employers, spontaneously adopted by a progressive vanguard, turn out to be the result of government intervention. For example, the US government during the Second World War constrained the wages that firms could pay and sought to stabilize employment in key industries through promoting standardized personnel practices. Desperate for labor in a tight market, firms responded by creating various benefits and job practices to be more 
attractive to a reticent labor force. Once these became widespread, they were effectively encoded as components of "modern personnel management" that any competitive player in a field would adhere to, rather than simply an exigent response to peculiar circumstances and government regulation (Baron, Dobbin, \& Jennings, 1986).

Diversity management today is one of the prizes of the human resource management profession. Yet the spread of diversity practices was not the result of individual firms spontaneously recognizing the wisdom of effective diversity management, but a more contentious collective process dating back decades. Companies faced new governmental demands to address employment equity in the wake of the 1964 Civil Rights Act, but they often had little clue what to do. Practically speaking, firms suspected of engaging in discrimination needed a response that would hold up in court. As Edelman (1992) indicates, firms that created a formal equal employment opportunity (EEO) office thereby withstood governmental scrutiny more effectively than those without such offices (whether or not the office was particularly effective). Observing this success, other employers subsequently created their own EEO offices in order to inoculate themselves from lawsuits, leading EEO offices to be a part of the standard package among modern employers. Yet such offices were not purely symbolic. Once in place, human resource executives became a constituency within the firm for policies that their own profession advocated or that had been adopted by "benchmark" firms, such as maternity leave and other best practices (e.g., Kelly \& Dobbin, 1999). As a result, organizations employing such executives became particular susceptible to adopting new HR practices as they became available.

The process of adopting and implementing new practices within individual firms can also be contentious and prone to peculiar tangents. Consider total quality management (TQM). As described in an outstanding study by Mark Zbaracki (1998), TQM often comes to an organization because a highlevel manager's curiosity is aroused by success stories that they hear. Such managers send subordinates out to investigate TQM's value, and based on the subordinates' reports, they "adopt" TQM (meaning, in effect, handing off its implementation to lower-level managers and crossing it off their to-do list). The role of the implementing managers is thereby converted from skeptical evaluator to promoter, conveying success stories internally as a means to persuade their employees of the value of a program they barely understand themselves. Core elements of TQM, particularly statistical process control, are difficult, so implementing managers avoid them in favor of the easier elements, such as brainstorming (by which participants seem to mean "thinking"). In the meantime, top management may be changing their mission statement to proclaim their commitment to "quality," and internal newsletters and external propaganda are celebrating bogus TQM success stories. Externally, these success stories become positive evidence for other potential TQM adopters, while internally, the rhetoric of success contrasts with the on-the-ground experience of employees. This gap in turn breeds employee skepticism and unwillingness to invest in the hard work of the core parts of TQM (such as statistical process control). Of course, employees only report up the successes and downplay the failures, so upper management comes to believe that TQM is working and perhaps conveys this impression to managers of other organizations. Begin cycle again.

The experience of organizations adopting TQM can help explain why managers seem particularly susceptible to managerial fads and fashions ( $c f$. Abrahamson, 1991). The world is an ambiguous place, with unending demands for performance. In the face of uncertainty, we often turn to our friends or competitors as models to figure out what to do. Yet knowing that they did something — say, TQM - is often much easier than knowing whether it worked. Moreover, even adoption itself is ambiguous: when our peers flaunt their TQM programs, did they rigorously delve into the details of their processes, or did they merely attach a new name to their old quality circles and call it "TQM"? In these circumstances, it is unsurprising that business fads seem to come and go on an annual basis.

The upshot of prior NIT research is that organizations often have offices and programs in place that are more symbolic than substantive, created to secure legitimacy rather than to accomplish real work; 
that organizations adopting new practices can do so for a variety of reasons, with varying implications for success; and that standard methods of program evaluation (e.g., comparing companies that have purportedly adopted TQM to those that have not) are problematic indeed. All of this has implications for the study of job design.

\section{Benefits of Trade}

New institutional theorists could benefit from knowing more about job design because it provides a distinctive content area for diffusion and adaptation. To critics, NIT would seem to have its own legitimate template for research: plug in a practice, find a network, and watch the diffusion process. Job design can provide greater "institutional detail" to better understand the sources and spread of best practices as work itself has evolved. The practice of job design draws much more explicitly on academic research than other practices that have spread, such as TQM or six sigma or downsizing. As a result, it can lay a more plausible claim to having a scientific basis than practices whose spread was driven by consultants and hype rather than evidence. At the same time, it is worth understanding how HR professionals, consultants, or other parties such as software vendors draw on, use, or even abuse the content of job design. Academic research does not become encased in amber when its insights are applied to the real world, as any academic whose research has been cited in the press can attest.

It is also informative to understand patterns of cross-industry diffusion. From the outside, job design seems largely based on jobs of the 1970s (e.g., routine assembly work; typing pools). But how have methods of job design that developed in one context spread to others, for better or worse? Peter Drucker wrote in 1949 that the methods that Henry Ford used in the mass production assembly line had diffused well beyond manufacturing, to agriculture, medicine, research, education, warfare, and even childrearing. My opening vignette described how familiar Taylorist methods are changing retail. Is there a similar observable spread of more humane job design techniques?

A second area worth exploring is job redesign in the context of professions such as law, medicine, and business. Professions, a central construct in institutional theory, were traditionally autonomous; indeed, the sovereignty of the professional is part of what distinguishes a profession from any other occupation. Now even the practice of medicine, the prototypical profession, has become more regularized through software-enabled disease tracking. The provision of health care has increasingly come to look like the drive-through window at a fast food chain, or perhaps the sales floor at Ann Taylor. An apt topic of research here is how job redesign for professions is enabled by information and communication technologies, and how professionals manage to resist encroachment on their sovereignty, either at the level of the individual (e.g. through job crafting) or at the collective level (e.g., through professional organizations or other forms of collective action). Institutionalists would focus here on the nature of professional networks and their ability to control what is defined as "legitimate" (e.g., through licensing standards).

Research on job design could also benefit from greater interaction with NIT, which could provide a broader sweep and a context for understanding efforts at job redesign. Before evaluating the effects of job redesign efforts, a reasonable question to ask is, "Why did this organization engage in job design in the first place?" "How is this workplace different from other workplaces?" Understanding the motives behind adoption also informs the extent and effectiveness of adoption. Motives highlighted by institutionalists include coercion (for instance, "Headquarters made us do it"); mimicry ("All our friends or competitors are doing it"); and normative emulation ("Our professional association and consultants told us that this is what organizations like ours are supposed to do"). 
The reason for a practice's adoption has important implications for its effectiveness. Weber, Davis, and Lounsbury (2009) examined the spread of stock exchanges among five dozen countries around the world during the 1980s and 1990s. They further examined how the motivations for adoption influenced the extent to which new exchanges were more or less successful 5 years out. They found that exchanges created by countries due to pressure from the IMF (i.e., coercion) were much less successful several years out than those created by countries that adopted because their neighbors, trading partners, or competitors had done so (mimicry and normative emulation). The latter were evidently able to draw on ongoing support and learning as their exchanges "grew up," so that what might have started as mere mimicry grew into something more.

A final area in which institutionalists might inform the study of job design is in understanding what categories are used to assess and change jobs. A thoughtful recent review by Grant et al. (2009) implied that a variety of categories had come and gone in evaluating jobs. But why these categories? What economic and social factors lead "autonomy" to be salient, as opposed to "safety"? How do these categories change over time, and why? Barley and Kunda (1992) document how the dominant themes in managerial rhetoric cycle between rationalistic approaches (such as Taylorism and systems design) and normative approaches (such as human relations and organizational culture), and posit that these correlate with long-term economic cycles. The job design literature has endured through several of these cycles-how might it reflect them?

\section{Conclusion}

The shift of the American economy from manufacturing to services has drastically changed the nature of jobs and organizations. Job design today takes place against a very different backdrop than it did during its formative years, when some of the long-dominant theories were constructed. Jobs are far more likely to be in services, such as retail, than in manufacturing. In a nation of shopkeepers, "task identity," "task significance," or "knowledge of the actual results of the work activities" can be somewhat constrained, and whatever autonomy sales clerks had extends only as long as their new electronic leash. The content of jobs changes rapidly, and insecurity rises at the micro level (due to the high turnover in services relative to manufacturing,) and the macro level (due to the increasing "offshoreability" of the American economy).

In these circumstances, few can devote themselves to developing a craft, or building a life narrative out of an expected career within an organization (Sennett, 2006). As a result, the task of job designenabling a meaningful life through work-becomes far more difficult. NIT has its origins in the effort to understand post-industrialism, and as such it has much to contribute to the study of job design in our current situation - and vice versa. I hope this brief survey points to some useful directions.

\section{Acknowledgements}

Prepared for "Putting job design in context: Cross-disciplinary, cross-level, and cross-cultural perspectives," a special issue of Journal of Organizational Behavior. I thank Adam Grant for comments on a prior draft. 


\section{Author biography}

Gerald F. Davis is the Wilbur K. Pierpont Collegiate Professor of Management at the Ross School of Business and Professor of Sociology, The University of Michigan. He received his PhD from Stanford University and previously taught at Northwestern University and Columbia University. He has published widely in management, sociology, and finance, and is the author of Managed by the Markets: How Finance Reshaped America (2009, Oxford University Press).

\section{References}

Abrahamson, E. (1991). Managerial fads and fashions: The diffusion and rejection of innovations. Academy of Management Review, 16, 586-612.

Applebaum, E., Bernhardt, A. D. \& Murnane, R. J. (Eds.). (2003). Low-wage America: How employers are reshaping opportunity in the workplace. New York: Russell Sage.

Barley, S. R., \& Kunda, G. (1992). Design and devotion: Surges of rational and normative ideologies of control in managerial discourse. Administrative Science Quarterly, 37, 363-399.

Baron, J. N, Dobbin, F. R., \& Jennings, D. P. (1986). War and peace: The evolution of modern personnel administration in US industry. American Journal of Sociology, 92, 350-383.

Bell, D. (1973). The coming of post-industrial society. New York: Basic Books.

Blinder, A. S. (2006). Offshoring: The next industrial revolution? Foreign Affairs, 85, 113-128.

Corak, M. (Ed.). (2004). Generational income mobility in North America and Europe. Cambridge UK: Cambridge University Press.

Davis, G. F. (2009). Managed by the markets: How finance reshaped America. Oxford: Oxford University Press.

Dibbell, J. (2007). The life of the chinese gold farmer. New York Times, June 1.

DiMaggio, P. J., \& Powell, W. W. (1983). The iron cage revisited: Institutional isomorphism and collective rationality in organizational fields. American Sociological Review, 48, 147-160.

Edelman, L. B. (1992). Legal ambiguity and symbolic structures: Organizational mediation of civil rights law. American Journal of Sociology, 97, 1531-1576.

Grant, A. M., Fried, Y., \& Juillerat, T. (2009). Work matters: Job design in classic and contemporary perspectives. In S. Zedeck (Ed.), APA handbook of industrial and organizational psychology. Washington, DC: American Psychological Association.

Kelly, E., \& Dobbin, F. (1999). Civil rights law at work: Sex discrimination and the rise of maternity leave policies. American Journal of Sociology, 105, 455-492.

Meyer, J. W., \& Rowan, B. (1977). Institutionalized organizations: Formal structure as myth and ceremony. American Journal of Sociology, 83, 41-62.

O'Connell, V. (2008). Retailers reprogram workers in efficiency push. Wall Street Journal, September 10.

Scott, W. R. (1995). Institutions and organizations. Thousand Oaks, CA: Sage.

Scott, W. R., \& Davis, G. F. (2007). Organizations and organizing: Rational, natural, and open system perspectives. Upper Saddle River, NJ: Pearson Prentice Hall.

Sennett, R. (2006). The culture of the new capitalism. New Haven, CT: Yale University Press.

Suchman, M. C. (1995). Managing legitimacy: Strategic and institutional approaches. Academy of Management Review, 20, 571-610.

Thompson, J. D. (1967). Organizations in action. New York: McGraw Hill.

Weber, K., Davis, G. F., \& Lounsbury, M. (2009). Policy as myth and ceremony? The global spread of stock exchanges, 1980-2005. Academy of Management Journal, (forthcoming).

Zbaracki, M. J. (1998). The rhetoric and reality of total quality management. Administrative Science Quarterly, 43, 602-636. 